\title{
Bonding Agent Underneath Sealant: Shear Bond Strength to Oil-Contaminated Enamel
}

\author{
Maria Cristina BORSATTO ${ }^{1}$ \\ Michelle Yamamoto THOMAZ ${ }^{1}$ \\ Marta Maria Martins Giamatei CONTENTE ${ }^{1}$ \\ Jaciara Miranda GOMES-SILVA ${ }^{1}$ \\ Talitha de Siqueira MELLARA ${ }^{1}$ \\ Rodrigo GALO ${ }^{2}$ \\ Regina Guenka PALMA-DIBB ${ }^{3}$ \\ ${ }^{1}$ Department of Pediatric Clinics, Preventive and Community Dentistry, \\ Ribeirão Preto Dental School, University of São Paulo, Ribeirão Preto, SP, Brazil \\ ${ }^{2}$ Department of Dental Materials and Prosthodontics, Ribeirão Preto Dental School, \\ University of São Paulo, Ribeirão Preto, SP, Brazil \\ ${ }^{3}$ Department of Restorative Dentistry, Ribeirão Preto Dental School, University of São Paulo, Ribeirão Preto, SP, Brazil
}

\begin{abstract}
This study evaluated in vitro the shear bond strength of a resin-based pit-and-fissure sealant (Fluroshield - F) associated with either an ethanol-based (Adper Single Bond 2 - SB) or an acetone-based (Prime \& Bond - PB) adhesive system under conditions of oil contamination. Mesial and distal enamel surfaces from 30 sound third molars were randomly assigned to 2 groups ( $\mathrm{n}=30$ ): I - no oil contamination; II - oil contamination. Contamination $(0.25 \mathrm{~mL}$ during $10 \mathrm{~s})$ was performed after $37 \%$ phosphoric acid etching with an air/oil spray. The specimens were randomly assigned to subgroups, according to the bonding protocol adopted: subgroup A - F was applied to enamel without an intermediate bonding agent layer; In subgroups B and C, SB and PB, respectively, were applied, light-cured, and then F was applied and light-cured. Shear bond strength was tested at a crosshead speed of $0.5 \mathrm{~mm} / \mathrm{min}$ in a universal testing machine. Means ( \pm SD) in MPa were: IA-11.28 ( \pm 1.84$)$; IIA-12.02 ( \pm 1.15$)$; IB-9.73 ( \pm 2.38$)$; IIB-9.62 ( \pm 2.29$)$; IC-28.30 $( \pm 1.63)$; and IIC-25.50 ( \pm 1.91$)$. It may be concluded that the oil contamination affected negatively the sealant bonding to enamel and the acetone-based adhesive system (PB) layer applied underneath the sealant was able to prevent its deleterious effects to adhesion.
\end{abstract}

Key Words: pit-and-fissure sealant, shear bond strength, oil contamination, adhesive system.

\section{INTRODUCTION}

In the light of the contemporary dental principles, as often as possible, noninvasive strategies have preferably been instituted rather than invasive healing treatments (1). Efforts have been focused on reducing patients' risk for caries by stimulating the adoption of preventive measures and highlighting the relevance of a partnership approach between patients and dentists for the ultimate success of caries control. Caries risk assessment is also an essential step to provide an individualbased, comprehensive treatment planning.
The high susceptibility of pits and fissures to carious attack and the rapid onset of the disease at these sites soon after tooth eruption are reported by several studies. In this context, treating caries-susceptible pits and fissures with resin sealants has been considered an outstanding adjunctive resource to oral health care strategies and fluoride therapy to decrease occlusal caries initiation and/or progression (2). Nevertheless, the preventive benefits of such treatment rely directly upon the ability of the sealing material to thoroughly fill pits, fissures, and/or anatomical defects and remain completely intact and bonded to the enamel surface

Correspondence: Profa. Dra. Maria Cristina Borsatto, Faculdade de Odontologia de Ribeirão Preto, USP, Departamento de Clínica Infantil, Odontologia Preventiva e Social, Avenida do Café, s/n, Monte Alegre, 14040-904 Ribeirão Preto, SP, Brasil. Tel: +55-16-3602-4114. Fax: +55-16-3633-0999. e-mail: borsatto@forp.usp.br 
for a lifetime, thus preventing caries from developing underneath the sealant restoration (3). Low utilization of sealants has been attributed to lack of confidence in their bonding to enamel and to the difficulty of achieving adequate dry field isolation (4).

Salivary pellicle, moisture, organic debris, blood and oil from air compressors and from hand-pieces have been also identified as potential contaminants of tooth surfaces that may lead to bonding failure (5).

Total etching with $30-40 \%$ phosphoric acid, rinsing and drying the surface to obtain a uniformly white, dull, chalk-like appearance is one of the steps on the sealant technique. In this context, the presence of oil in the air/water syringes from air compressors could create a potential source of contamination coating the enamel surface after the acid etching step. This contamination must be a matter of concern to the professional, since their presence is relatively unknown, and their results are unexpected.

Several studies have shown the benefits of adding a bonding agent layer between the etched enamel and the sealant to increase the bond strength in the face of moisture and salivary contamination (6-8).

The literature is still scarce in articles investigating the oil contamination of tooth substrates and its effects on adhesion (9-12). In addition, there appear to be no study evaluating the sealant technique and the association of adhesives systems as intermediary bonding agents prior to sealant placement under conditions of oil contamination. Therefore, this study assessed in vitro the shear bond strength of a resin-based pit-and-fissure sealant associated with 2 adhesives systems as intermediate agents under air compressor oil contamination.

\section{MATERIAL AND METHODS}

This study was approved by the Research Ethics Committee of Ribeirão Preto Dental School, University of São Paulo. Freshly extracted sound human third molars were hand scaled and cleaned with water/ pumice slurry in rotating bristle brushes to remove calculus and root-adhered debris, and were examined under a $\times 20$ magnifier to discard those with structural defects. Thirty teeth were selected for the study and stored in $0.9 \%$ saline with $0.4 \%$ sodium azide at $4{ }^{\circ} \mathrm{C}$. Prior to use, the teeth were washed in running water to eliminate storage solution residues, the roots were removed $3 \mathrm{~mm}$ below the cementoenamel junction and the crowns were embedded in polyester resin using polyvinyl chloride rings $(2.1 \mathrm{~cm}$ diameter and 1.1 $\mathrm{cm}$ height). After resin polymerization, the rings were discarded and the mesial and distal enamel surfaces were ground wet with \#320- to \#400-grit silicon carbide (SiC) papers (Buehler Ltd., Lake Bluff, IL, USA) in a low-speed polishing machine (Politriz DP-9U2; Struers, $\mathrm{A} / \mathrm{S}$, Copenhagen, Denmark). The specimens were then hand polished with wet \#600-grit $\mathrm{SiC}$ paper to obtain flat, smooth test surfaces, which were cleaned by rubber cup/pumice prophylaxis for $10 \mathrm{~s}$. For standardization, the bonding sites were demarcated by attaching a piece of insulating tape with a 3-mm-diameter central hole on was attached to each surface. The 60 test surfaces were randomly assigned to 2 groups $(\mathrm{n}=30)$ of equal size, as follow: I - oil contamination; II - no oil contamination. In oil contaminated group, before the adhesive system/ sealant application, the acid-etched enamel bonding site was contaminated for $10 \mathrm{~s}$ with one spray $(25 \mu \mathrm{L})$ of air/oil from air compressor at a distance of 2 to $3 \mathrm{~cm}$, covering the enamel surface to be bonded. The enamel surfaces were etched with a $35 \%$ phosphoric acid gel (Scotchbond etchant; 3M/ESPE, St. Paul, MN, USA ) for $15 \mathrm{~s}$, rinsed thoroughly for $15 \mathrm{~s}$, dried with a mild, oil-free air stream to obtain a uniformly white, dull, chalk-like appearance.

The following materials were tested: a filled resin-based pit-and-fissure sealant [Fluroshield; Dentsply/Caulk, Milford, DE, USA] and single-bottle ethanol-based adhesive system [Adper Single Bond 2; 3M ESPE] and a single-botlle acetone-based adhesive system [Prime \& Bond 2.1; Dentsply/Caulk] were used according to manufacturers' instructions.

Then the groups were randomly assigned to 3 subgroups, according to the bonding protocol adopted.

Subgroup A - Fluroshield was applied to the demarcated etched enamel site and light-cured for $20 \mathrm{~s}$.

Subgroup B - Adper Single Bond 2 (SB) was applied to the etched enamel bonding site in a uniform layer, slightly thinned with a mild, oil-free air stream and light-cured for $10 \mathrm{~s}$ with a visible light curing unit (XL $3000 ; 3 \mathrm{M} / \mathrm{ESPE}$ ) with $450 \mathrm{~mW} / \mathrm{cm}^{2}$ output, as measured with a curing radiometer (Demetron Research Corp., Danbury, CT, USA). Next, Fluroshield was applied and light-cured for $20 \mathrm{~s}$.

Subgroup C - A uniform layer of Prime \& Bond 2.1 (PB) bonding agent was applied as described in subgroup B and light-cured for $20 \mathrm{~s}$ with the same light 
curing unit. Next, Fluroshield was applied and lightcured for $20 \mathrm{~s}$.

The tested adhesive system and the sealant were carefully applied to tooth surface with disposable brush tips (Microbrush Corporation, Orlando, FL, USA) to avoid excess and pooling of adhesive along the edges of the insulating tape that could affect tension distribution during the shearing test and the validity of results.

After completion of the bonding protocols, the specimens were individually fixed in a metallic clamping device (developed at the Houston Biomaterials Research Center, University of Texas Dental Branch, Houston, TX, USA and manufactured at the Precision Workshop of Ribeirão Preto Dental School, University of São Paulo, Brazil)that secured the test dentin surface parallel to a flat base. A split bisected polytetrafluoroethylene jig was positioned on the tooth/resin block, providing a cylindrical cavity (4 $\mathrm{mm}$ high $\mathrm{x} 3 \mathrm{~mm}$ diameter) that was coincident with the demarcated enamel bonding site. Sealant was inserted into the jig in increments, each polymerized for $20 \mathrm{~s}$. As the cavity was filled, the specimen was released from the clamping device and jig, leaving a sealant cylinder ( $4 \mathrm{~mm} \times 3 \mathrm{~mm}$ ) adhered to the enamel surface.

After 24-h storage in distilled water at $37^{\circ} \mathrm{C}$, shear bond strength was determined using a knife-edge blade in a universal testing machine (Mod. MEM 2000; EMIC Ltda, São José dos Pinhais, PR, Brazil) at a crosshead speed of $0.5 \mathrm{~mm} / \mathrm{min}$ with a $50 \mathrm{kgf}$ load cell. The means (in $\mathrm{MPa}$ ) and standard deviations were calculated and data were analyzed statistically by one-way ANOVA. Because sample distribution was not normal, the t-test non-parametric test was used for multiple comparisons at $1 \%$ significance level.

\section{RESULTS}

Shear bond strength means and standard deviations for oil-contaminated and non-contaminated groups are shown in Table 1.

No statistically significant difference $(\mathrm{p}>0.01)$ was observed among subgroups IA, IIA, IB and IIB, which means that sealant association with the ethanolbased adhesive system did not prevent the deleterious effects of oil contamination on adhesion.

The association of Prime Bond 2.1 adhesive system to Fluroshield sealant increased the shear bond strength with significantly higher mean bond strength values $(\mathrm{p}<0.01)$ compared to the others subgroups.

\section{DISCUSSION}

Adhesive procedures can be compromised by field contamination that results in a decrease in bonding strength (9-11). The presence of oil in the air/water syringes from air compressors could create a potential source of contamination coating the enamel surface on the sealant application technique, since rinsing and drying the surface to obtain a uniformly white, dull, chalk-like appearance is required after the acid etching step. Effective oil filters on air lines are not used in most dental offices and thus the oil that comes from air compressors provides an unpredictable clinical outcome and a potential negative factor in dental adhesion because its presence is relatively unknown, and their results are unexpected. Air pureness depends on the presence of effective filters and adequate maintenance of compressors (5). The literature is still scarce in articles investigating oil contamination on dental substrates and its effects on adhesion.

In the present study, it was observed that oil contamination affected negatively the resin sealant bonding to enamel. Enamel was contaminated after acid etching in order to simulate the clinical situation of drying (with oil contaminated compressed air lines) the enamel surface during sealant placement. Some authors $(11,12)$ have reported that handpiece oil contamination before the application of the adhesive system interfered

Table 1. Shear bond strength means (MPa) to the experimental groups.

\begin{tabular}{lc}
\hline Subgroups & Means $( \pm \mathrm{SD})$ \\
\hline IA - F applied to noncontaminated enamel & $12.28 \pm 1.84 \mathrm{a}$ \\
IB - SB and F applied to noncontaminated & $12.02 \pm 1.15 \mathrm{a}$ \\
enamel & $9.73 \pm 2.38 \mathrm{a}$ \\
IIA - oil contamination + F & $9.62 \pm 2.29 \mathrm{a}$ \\
IIB - oil contamination + SB and F & $28.30 \pm 1.63 \mathrm{~b}$ \\
IC - PB and F applied to noncontaminated & \\
enamel & $25.50 \pm 1.91 \mathrm{~b}$ \\
\hline IIC - oil contamination + F and PB
\end{tabular}

Fluroshield $=$ F; Adper Single Bond $2=\mathrm{SB}$; Prime $\&$ Bond $=$ PB. Different letters indicate statistically significant difference $(p<0.01)$. 
with bonding to enamel. However, others authors $(9,10)$ stated that handpiece lubricant did not significantly affect enamel bond strengths. Rosa et al. (13) observed little effect on bonding of adhesive systems to enamel under handpiece oil contamination performed after acid etching. It is important to point out that different types of adhesive systems were tested by those authors. Additionally, to the best of our knowledge, no study has yet evaluated oil contamination on sealant technique.

Over the last decades, the application of an intermediate bonding agent layer underneath the sealant has been widely suggested. The findings of several studies $(4,6,14-17)$ have shown that the use of adhesive systems along with resin sealants may improve bonding to etched enamel under dry and contamination conditions. It is likely that solvents, such as ethanol and acetone, present in the currently available single-bottle adhesives are able to remove any residual moisture from the etched enamel, carrying the resin monomers into close adaptation with the surface $(15,18)$. Furthermore, the hydrophilic monomers present in these materials increase the surface wetting and resin penetration, counteracting the adverse effects of organic contamination (saliva or oil) on bonding to tooth structure (17).

In the present study the association of the sealant with Prime \& Bond adhesive system increased the bond strength to enamel. The ethanol-based adhesive system used in the present study (Single Bond) contains water as a co-solvent, which produces lower volatility compared to the acetone-based adhesive system (Prime \& Bond). This cleansing effect of the acetone solvent could be responsible for the higher bond strength obtained for the sealant associated with Prime \& Bond adhesive system.

The lack of reported studies testing the same methodology and materials did not allow stating a reliable comparison with outcomes in the literature.

It is important to emphasize that this paper in no way suggests that improper technique for sealant placement can be advocated at all. However, it is estimated that a large number of dental offices have oil contamination in their air lines (5), although manufacturers recommend periodic changes of the filters. Thus, contamination of etched enamel might occur. Our expectation is that the findings of this study may help improveing clinician confidence in sealant success, even in circumstances of application that are far less than ideal.

Based on the findings of this study and within the limitations of an in vitro investigation, the follow- ing conclusions can be drawn: 1. Oil contamination affected negatively the resin sealant bonding to enamel; 2. Sealant association with the acetone-based adhesive system was able to prevent the deleterious effects of oil contamination on adhesion.

\section{RESUMO}

Este estudo avaliou in vitro a resistência ao cisalhamento (RC) de um selante resinoso [Fluroshield (F); Dentsply/Caulk] em associação com um sistema adesivo com solvente a base de etanol [Adper Single Bond 2 (SB); 3M/ESPE] ou a base de acetona [Prime \& Bond (PB); 3M/ESPE] após contaminação com óleo do esmalte. Superfícies mesiais e distais de esmalte de 30 terceiros molares hígidos foram aleatoriamente alocadas em 2 grupos ( $n=30)$ : I - contaminação com óleo; II - sem contaminação. A contaminação foi realizada $(0,25 \mathrm{~mL} ; 10 \mathrm{~s})$ com um jato de ar/ óleo após o condicionamento do esmalte com ácido fosfórico a $37 \%$. Os espécimes foram aleatoriamente alocados em subgrupos, de acordo com a técnica adesiva empregada: A - F foi aplicado sobre o esmalte condicionado sem sistema adesivo; $\mathrm{B}-\mathrm{SB}+\mathrm{F}$; $\mathrm{C}-\mathrm{PB}+\mathrm{F}$. RC foi testada em uma máquina universal de ensaios $(0,5 \mathrm{~mm} / \mathrm{min} ; 50 \mathrm{kgf})$ e os dados analisados por ANOVA e t-teste $(\alpha=0,01)$. As médias de RC em MPa foram: IA-11,28 $( \pm 1,84)$; IIA-12,02( $\pm 1,15)$; IB-9,73 $( \pm 2,38)$; IIB-9, $62( \pm 2,29)$; IC- 28,30 ( \pm 1.63$)$; e IIC-25,50 $( \pm 1,91)$. Conclui-se que a contaminação com o óleo afetou a adesão do selante resinoso ao esmalte e o sistema adesivo com solvente a base de acetona (Prime $\&$ Bond) aplicado sob o selante foi capaz de impedir os efeitos deletérios da contaminação com óleo.

\section{REFERENCES}

1. Lygidakis NA,Dimou G,Stamataki E.Retention of fissure sealants using two different methods of application in teeth with hypomineralised molars (MIH): A 4 year clinical study. Eur Arch Paediatr Dent 2009;10:223-226.

2. Splieth CH, Ekstrand KR, Alkilzy M, Clarkson J, MeyerLueckel H, Martignon S et al.. Sealants in Dentistry: Outcomes of the ORCA Saturday Afternoon Symposium 2007. Caries Res 2010;44:3-13.

3. Dennison JB, Straffon LH, Smith RC. Effectiveness of sealant treatment over five years in an insured population. J Am Dent Assoc 2000;131:597-605.

4. Hevinga MA, Opdam NJ, Frencken JE, Bronkhorst EM, Truin GJ Microleakage and sealant penetration in contaminated carious fissures. J Dent 2007;35:909-914.

5. Gooch BF, Griffin SO, Gray SK, Kohn WG, Rozier RG, Siegal $\mathrm{M}$ et al.. Preventing dental caries through school-based sealant programs: updated recommendations and reviews of evidence. $\mathrm{J}$ Am Dent Assoc 2009;140:1356-1365.

6. Gomes-Silva JM, Torres CP, Contente MM, Oliveira MA, PalmaDibb RG, Borsatto MC. Bond strength of a pit-and-fissure sealant associated to etch-and-rinse and self-etching adhesive systems to saliva-contaminated enamel: individual $v s$. simultaneous light curing. Braz Dent J 2008;19:341-347.

7. Borsatto MC, Corona SA, Alves AG, Chimello DT, Catirse AB, Palma-Dibb RG. Influence of salivary contamination on marginal microleakage of pit and fissure sealants. Am J Dent 2004;17:365- 
367.

8. Torres CP, Balbo P, Gomes-Silva JM, Ramos RP, Palma-Dibb $\mathrm{RG}$, Borsatto MC. Effect of individual or simultaneous curing on sealant bond strength. J Dent Child 2005;72:31-35.

9. Xie J, Powers JM, McGuckin RS. In vitro bond strength of two adhesives to enamel and dentin under normal and contaminated conditions. Dent Mater 1993;9:295-299.

10. Powers JM, Finger WJ, Xie J. Bonding of composite resin to contaminated human enamel and dentin. J Prosthodont 1995;4:28-32.

11. Knight JS, Draughn R, Evans MD. Effects of handpiece lubrication on resin-based composite bond strength to enamel. Am J Dent 1999;12:1116-1118.

12. Matos AB, Oliveira DC, Vieira SN, Netto NG, Powers JM. Influence of oil contamination on in vitro bond strength of bonding agents to dental substrates. Am J Dent 2008;21:101-104.

13. Rosa BT, Heymann HO, Swift EJ, Perdigão J, Ritter AV. Shear bond strength of one-bottle adhesive to oil-contaminated enamel. J Esthet Dent 2000;12:139-145.
14. Choi JW, Drummond JL, Dooley R, Punwani I, Soh JM. The efficacy of primer on sealant shear bond strength. Pediatr Dent 1997; 19:286-288.

15. Fritz UB, Finger WJ, Stean H. Salivary contamination during bonding procedures with a one-bottle adhesive system. Quintessence Int 1998;29:567-572.

16. Tulunoglu O, Bodur H, Uctasli M, Alacam A. The effect of bonding agents on the microleakage and bond strength of sealant in primary teeth. J Oral Rehabil 1999;26:436-441.

17. Gomes-Silva JM, Torres CP, Contente MMMG, Oliveira MAHM, Palma-Dibb RG, Borsatto MC. Bond strength of a pit-and-fissure sealant associated to etch-and-rinse and self-etching adhesive systems to saliva-contaminated enamel: individual vs. simultaneous light curing. Braz Dent J 2008;19:341-347.

18. Hebling J, Feigal RJ. Use of one bottle adhesive as an intermediate bonding layer to reduce sealant microleakage on saliva-contaminated enamel. Am J Dent 2000;13:187-191.

Accepted March 17, 2010 